\title{
Surviving on Half a Hectare of Land An Introduction to the Issues Surrounding Smallholder Farming in Malawi
}

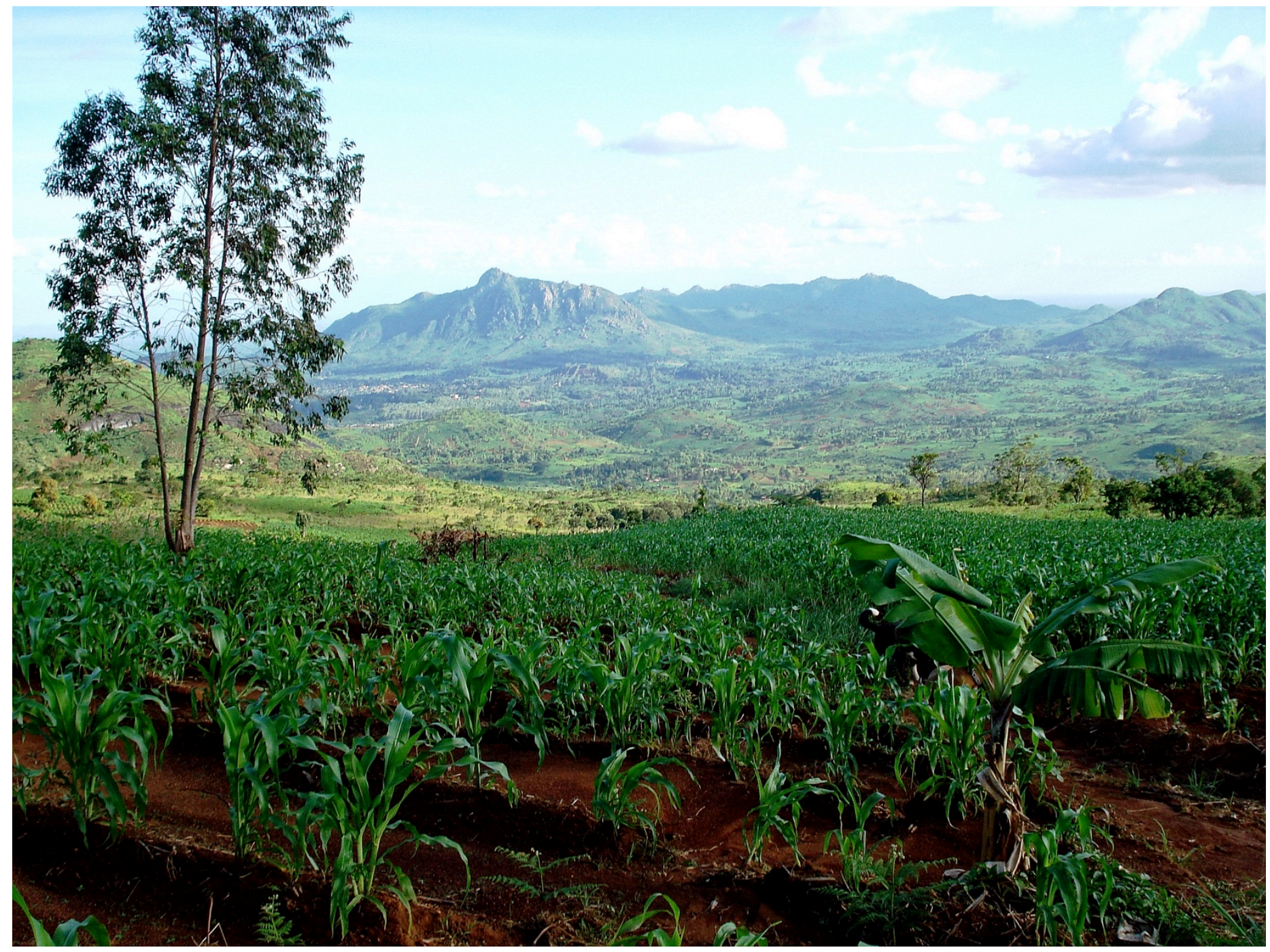


S. J. Carr,

Private Bag 5,

Zomba,

Malawi

Email: carrstephen528@gmail.com

This paper is published under the Plant Production Systems group, Wageningen University. Hanna Kool and Ken Giller helped with editing the final version.

Plant Production Systems website: http://www.wur.nl/en/expertise-services/Chairgroups/Plant-Sciences/Plant-Production-Systems-Group.htm

Please cite as follows: Carr, S.J. (2017). Surviving on Half a Hectare of Land: An Introduction to the Issues Surrounding Smallholder Farming in Malawi. Plant Production Systems. Wageningen University, Wageningen. 36 pp.

ISBN: 978-94-6343-607-6

DOI: http://dx.doi.org/10.18174/417831

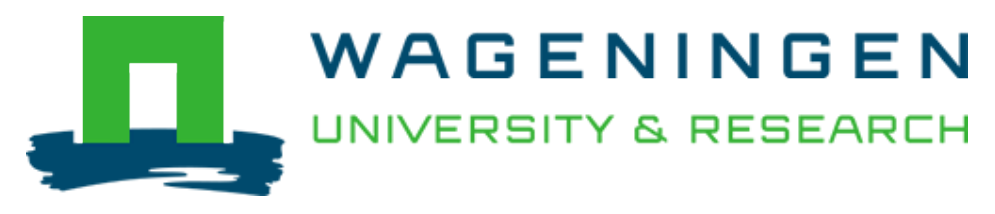




\section{BACKGROUND}

Not everyone dealing with agricultural issues in Malawi appreciates the fact that smallholders in this country face challenges which are unique in Africa. No other country in Sub-Saharan Africa has population densities of up to 250 to the square $\mathrm{km}$ combined with a single rainy season of five months. The five areas with comparable population densities to those of Malawi have rain all the year or have two rainy seasons. Their smallholders can grow perennial food crops and, on a small piece of land, establish high value perennial cash crops such as tea, coffee and vanilla. On the other hand farmers living in areas with comparable rainfall to Malawi occupy comparatively thinly populated countries and so are able to grow larger areas of food crops to meet their needs and larger areas of low value annual cash crops such as cotton and legumes and so raise some cash for their family requirements.

Many Malawian smallholders can adopt neither of these options. The overwhelming majority cannot grow coffee or tea because of inadequate rainfall and the limitations of small farm size means that they can only produce small amounts of any crop other than their basic staples. About 15\% grow burley tobacco but that number cannot be increased as the crop is already over-produced. A further $10 \%$ raise cash from rice, groundnuts, maize and horticultural crops but the great majority have to allocate all of their land to producing food for the family and rely on low paid casual occupations to raise the cash that they need. It is for this reason that the majority of rural Malawians are classified as being below the poverty line. An appreciation of this situation can help in an understanding of the current state of smallholder farming in Malawi and it is hoped that these notes may cast a little more light on the plight of this country's millions of small scale farmers and provide some indicators as to how best they can be helped.

\section{Section 1}

\section{LAND}

Smallholder agriculture in Malawi is largely defined by land availability. While the mean land holding is 0.96 hectares per family $38 \%$ have less than 0.5 hectares and only $27 \%$ have more than one (Table 1). From these areas smallholder farmers have to provide for the needs of their families with one rainy season lasting 4 or 5 months. 
Table 1. Percentage distribution of households by holding size

\begin{tabular}{|l|l|l|l|l|l|l|l|}
\hline & \multicolumn{7}{|c|}{ Holding size (ha) } \\
\hline 0.964 & $<0.1$ & $0.1-0.19$ & $0.2-0.49$ & $0.5-0.99$ & $1.0-1.99$ & $2.0-+$ & Total \\
\hline Mean & 5 & 7 & 26 & 34 & 19 & 8 & 100 \\
\hline
\end{tabular}

Source: National Census of Agriculture and Livestock 2006/07 (NSO, 2010); Table 2.4.

The reason for these small plot sizes can be found in the rapid growth in the country's population from 730,000 at the time of the first census in 1901 to over 16 million in 2016 (Figure 1). At the time of independence holding sizes varied from an average of 3 hectares in the North and Centre to 1.7 hectares in the South. Overall at that time families were able to allocate an average of 1.25 ha to maize (Pike \& Rimmington, 1965), which was more land than the total farm size for the great majority today. Twenty years earlier than that most families could use 7-year bush fallows to restore the fertility of their soils. The change from a system in which land was not a constraint and in which soil fertility could be maintained without the use of external inputs to one of serious land shortage and degraded soils has taken place in less than two generations and has allowed little opportunity for a gradual adaptation.

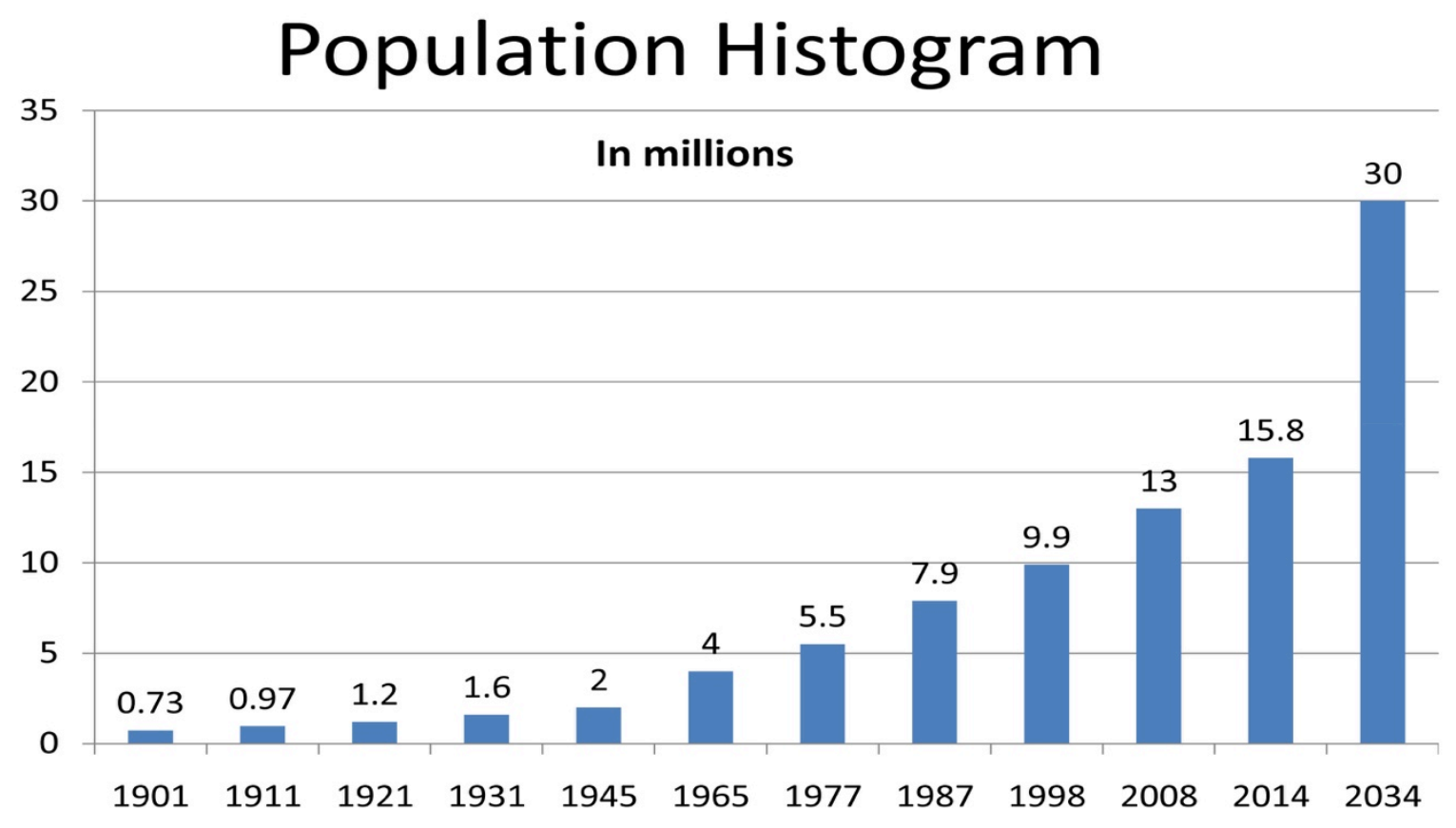

Figure 1. Estimated population growth in Malawi from 1900 to 2034. Source: National Statistical Office: National Population Census Reports for respective census years. 
Population growth is set to continue and by 2034 the National Statistics Office predicts a rural population of 23.4 million consisting of some 5 million families (NSO, 2008). If the current pattern of rural employment continues then it can be expected that at least $85 \%$ of these will be smallholder farmers (NSO, 2014) giving a total of 4.2 million. If these are to have access to the same small amount of land as those currently farming (0.96 ha) they will need just over 4 million ha of cultivable land. FAO estimates that the total area of land suitable for arable cropping is 4.1 million ha (Country Representative of FAO Lilongwe Malawi, personal communication). There has been considerable discussion about allocating substantial areas of land for large scale mechanised farming over the next few years. These plans have not included any reference as to where the displaced rural families will find a living. Urban planners are already concerned at the prospect of a trebling of the urban population by 2034 and are unlikely to welcome the influx of millions of people evicted from their land to make way for large scale farm enterprises. When Scottish smallholders were driven off their land to make way for large scale estates they suffered terrible privation but the Americas and Australia were warmly welcoming immigrants and so they had some hope of starting a new life. No such door appears available for Malawian smallholders who might be driven from their homes and farms. In reality the amount of opposition which such expulsions would provoke means that it is likely that Malawian agriculture will continue to be dominated by small scale farmers for the next 18 years. The following sections will be based on that assumption.

\section{Section 2 \\ Soils}

Accounts of the country's soils at the time of Independence describe some of the main plateau's red, sandy clay soils as "fertile but intensively cultivated". The use of the description "fertile" has at times been carried forward in documents referring to the situation today. This ignores the fact that for many years these soils have consistently had more nutrients removed from them than have been replaced (Figure 2). The World Bank has estimated that Malawian soils are losing $80 \mathrm{~kg}$ of nutrients per hectare per year from crop removal and surface erosion (World Bank, 2004; Section 3.22). This may be an overestimate in fields producing low yields but in virtually every area of the country the removal of nutrients has outweighed their replacement. In consequence nitrogen deficiency is almost universal on 
smallholdings across the country and is the main reason for low maize yields. Phosphate deficiency is not as ubiquitous but is still a constraint on many small farms. Malawi is fortunate in that minor element deficiencies other than sulphur are confined to comparatively limited areas of the country. Because evaporation exceeds precipitation in all but one month in an average year there is limited leaching and as a result there have been only comparatively small areas where soil acidity is the major constraint to maize production. With the ever increasing intensity of cultivation the occurrence of soil acidity has become more widespread as revealed by the most recent soil survey maps. In the absence of significant lime deposits this may become a serious constraint on maize production in some areas.

The World Bank estimates that about $8 \mathrm{~kg}$ per hectare of lost nutrients are replaced from all organic sources each year. Livestock ownership is strictly limited and animal numbers in relation to the farmed area are low. $6 \%$ of smallholders own a bovine and $26 \%$ own goats or sheep but numbers are small and work out at 1.2 animals per hectare of cultivated land. Compost making is difficult when the availability of abundant organic materials occurs at the end of the rains and then there are six months of dry weather during which compost heaps have to be watered regularly if the material is to be of use for the next cropping season. This is not practicable for the overwhelming majority of the population. In the absence of organic manure the soils which have been cultivated for long periods of time have limited microbial populations which in turn can adversely affect plant health and growth.

This decline in soil nutrients became obvious some years ago and was clearly demonstrated by the work of a Harvard team which analysed the results of a wide range of experiments on farmers' fields which had been supervised by research workers. They found that the yield of maize in the unfertilised plots had fallen steadily from 2,970 kg per ha in 1972 to 1,550 kg per ha in 1993 (HIID, 1994).

Experienced agronomists, from a range of backgrounds (e.g. Byerlee et al., 1994; Heisey \& Mwangi, 1996; Heisey \& Smale, 1995; USAID, 2000), have long supported the almost universal conviction of Malawian farmers that it is the shortage of plant nutrients in their soils which is the main reason for their poor yields. Any strategy for raising maize production in Malawi which does not address the issue of nutrient depletion in the country's soils has very little chance of success. 


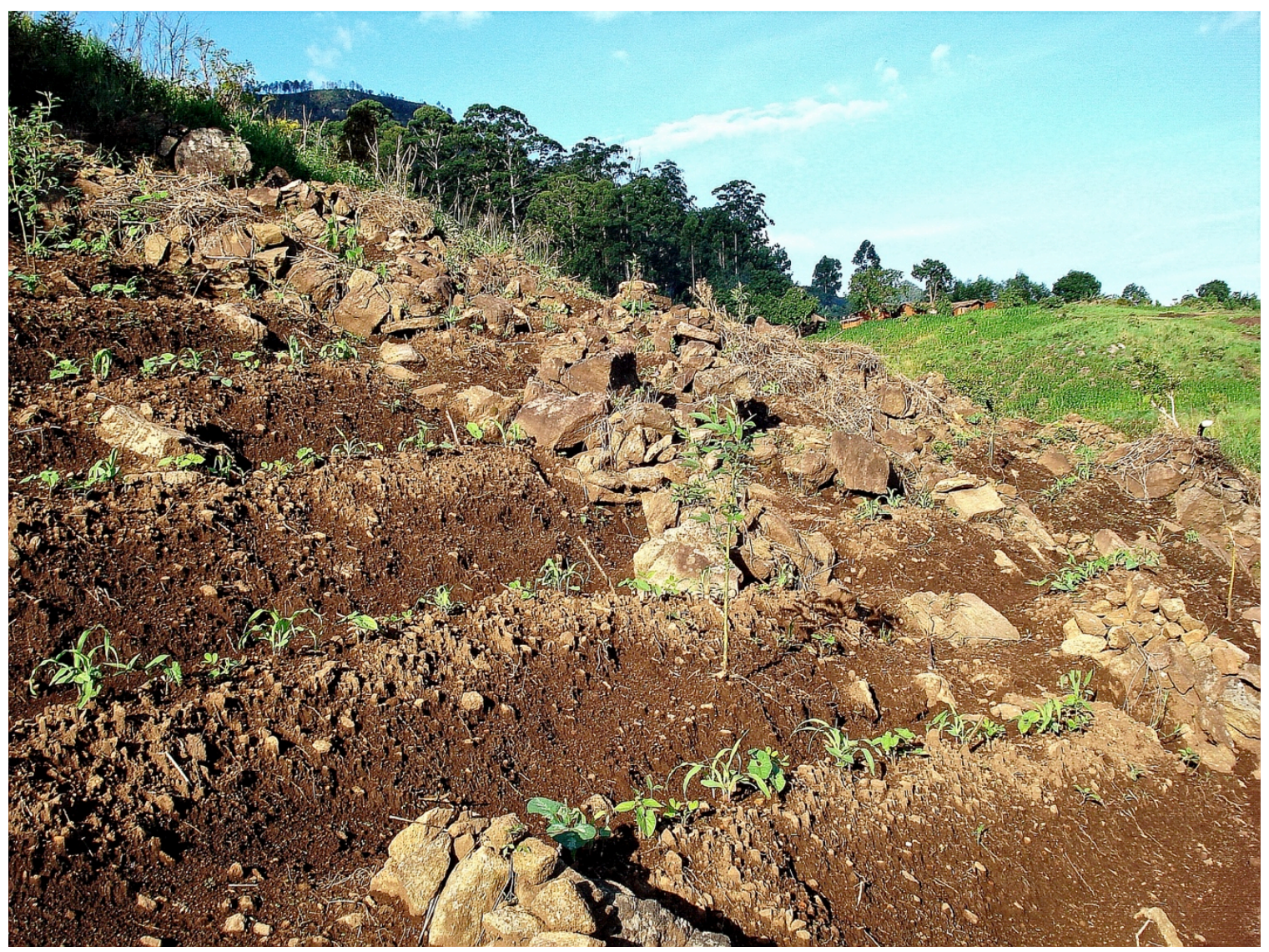

Figure 2. There is a shortage of fertile soil.

Section 3

\section{Climate}

The growing season in Malawi for rain fed crops is confined to some five months between November and April. During that period the long term average rainfall for all the metrological stations in Malawi is over $600 \mathrm{~mm}$. Even in the 2015/16 season when the country was affected by a strong El Niño event, $82 \%$ of the stations recorded over $600 \mathrm{~mm}$ during the growing season. Unless there are quite exceptional dry periods during the growing season, such as occurred in February 1992. This amount of rainfall is adequate for well nourished maize plants to produce a good crop and in 2016 those farmers who could afford adequate fertiliser had excellent maize yields. Farmers in the U.S. State of Iowa obtain average yields of 9.6 tons of maize to the hectare with an average growing season rainfall of $560 \mathrm{~mm}$. The main challenge of the climate for maize growers in Malawi is the intensity of rainfall in the second half of December and throughout January. This interferes with weeding, results in waterlogging and is accompanied by 
limited sunshine. It is for this reason that drier years often result in better maize yields. A second challenge to both farmers and to meteorologists is the variation in rainfall patterns. This can be seen in the longer term with the level of Lake Malawi (which is rain fed from its catchment) varying by 140 metres in recent centuries (Owen et al., 1990) whilst the rainfall graph of any recording station demonstrates a pattern of recent wide variation (see Figure 3). This led the team carrying out the UNDP Climate Change Country Profile of Malawi (McSweeney, New, \& Lizcano, 2010) to write "Year to year variability in rainfall is very strong in Malawi and this makes it difficult to identify long term trends. Observations of rainfall over Malawi do not show statistically significant trends and there is no evidence of persistent decreases."

It is because of this variability that it is so essential that farmers have the resources to ensure that their crops are adequately fed and therefore capable of withstanding the short periods of stress which frequently occur and damage poorly developed plants with inadequate root systems.

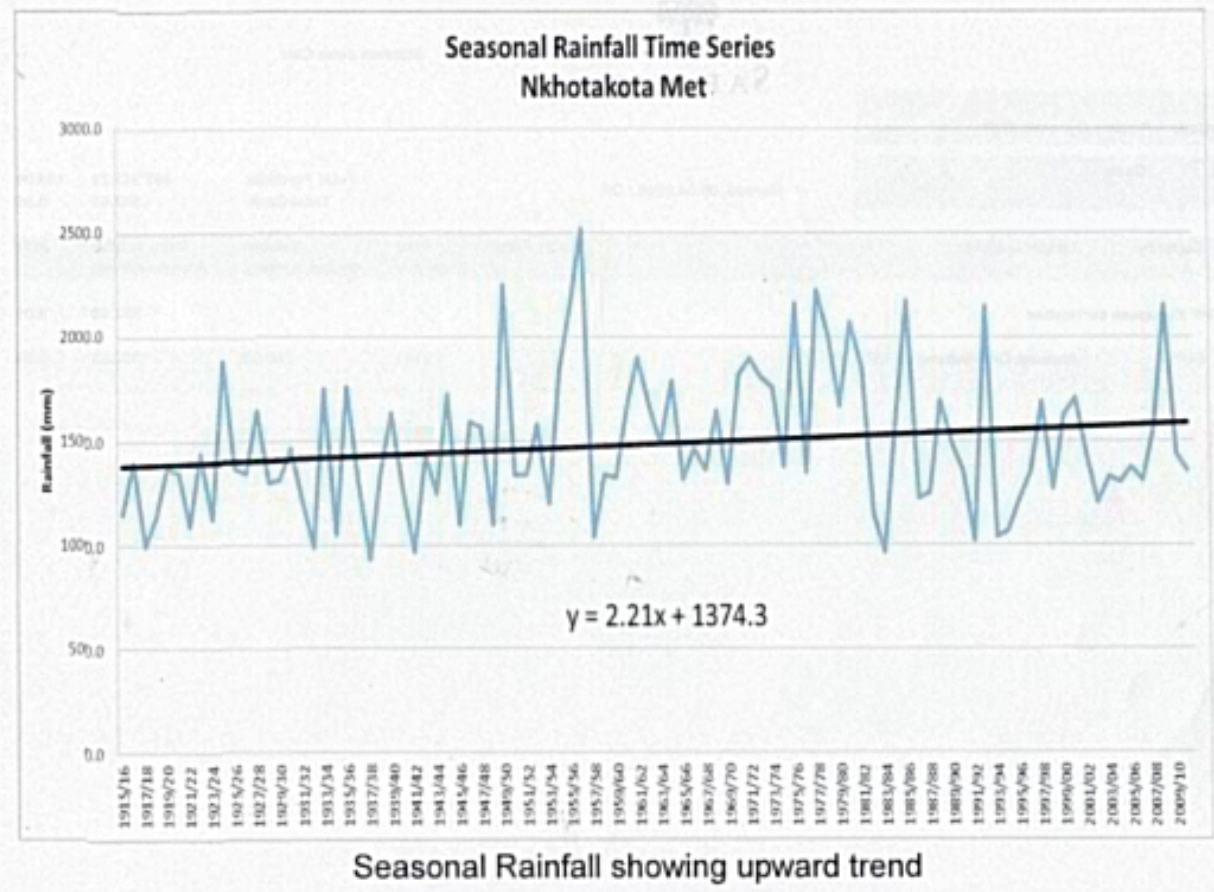

Figure 3. Seasonal rainfall recordings at Nkhotakota Met from 1915 to 2009 showing a wide variation. Source: National Meteorological Services Seasonal Rainfall Time Series. 
The fundamental climatic challenge to Malawian farmers, however, is the length of the dry season. This precludes the great majority from growing the perennial cash crops which provide the basis of prosperity in other African countries with a rainfall pattern better distributed throughout the year. Apart from micro-ecological areas Malawian farmers cannot grow coffee or tea, cacao, rubber, oil palm or vanilla, but are confined to lower value annual crops for their cash income. Likewise they are neither able to grow a perennial food staple like plantains which feed other densely populated areas, nor grow two successive food crops in a year in the absence of a source of irrigation. It is this rainfall pattern combined with the restricted access to land which are crucial factors in the persistence of rural poverty in the country and which make intensification of production during the limited growing season so important. 


\section{Section 4}

\section{CROPS}

\section{MAIZE}

Those not fully familiar with rural Malawi express surprise at the dominance of maize in the farming system as they pass through unbroken fields of the crop with few signs of a diversified agriculture. Presumably the same reaction is true for rice farmers of Bangladesh or the cassava growers of the wettest, densely populated areas of the West Coast of Africa who likewise demonstrate little crop diversification. The reason for these choices is that farmers have selected the crop best suited to their particular conditions and environment. Maize is the highest yielding grain crop developed by humans and is therefore the obvious choice as a staple for farmers who have severely limited access to land and have a climate appropriate to the crop. The climate of the Malawian Plateau (excluding the Rift Valley) is almost identical to that of the part of Mexico in which early man developed maize and where it remains the dominant crop. Both areas have comparable temperatures, a four and a half to five month rainy season and an average annual rainfall of 600 to $800 \mathrm{~mm}$. It is therefore unsurprising that it has become the staple crop of choice for Malawian farmers and it has served them well.

Although the crop was introduced by the Portuguese on to the Mozambican coast in the $17^{\text {th }}$ Century, it did not spread into Malawi until the climate became wet enough in the $19^{\text {th }}$ Century (Miracle, 1966). It then rapidly replaced the sorghums and millets which had been the staples during the long dry period from the end of the $14^{\text {th }}$ Century. Various strains of maize were introduced by missionaries and others but local farmers selected out flint types with a hard endosperm. These are highly resistant to weevil attack in store and were best suited to the local method of extracting the flour in a mortar.

CULTIVATION: The land is cleared by burying weeds and leafy material and burning the maize stalks. Malawian farmers, like their European counterparts who had to deal with wheat straw, soon found that burying maize stalks led to serious losses in the following crop. 
Table 2. Response of maize to various methods of land preparation.

\begin{tabular}{ll}
\hline TREATMENT & Yield of maize in kg per hectare \\
\hline Stover burnt & 3,456 \\
Stover buried & 3,142 \\
Stover left as mulch & 2,592 \\
Stover removed & 2,985 \\
\hline
\end{tabular}

Department of Agricultural Research Chitedze Station 1958, quoted in Saka, Green, and Ng'ong'ola (1995); Table 3.18, page 61.

Losses from burying stover in the trial were comparatively small because this was research plot soil with a high nitrogen content (Table 2). Work in both Zimbabwe and Malawi on smallholder soils has shown yield losses of up to $25 \%$ from burying stover. The reasons for this are well known. Both wheat and maize withdraw virtually all the nitrogen from their stems as they mature so as to boost the protein content of their grain. In consequence the stover contains virtually no nitrogen and when buried the bacteria have to draw on other sources of nitrogen in the soil to metabolise the stalks. In a soil already short of nitrogen this robs the young maize plants of essential nutrients just when they are most needed. In the case of mulching the benefits of moisture conservation and protection from rain impact might offset the losses from losing all the non-nitrogenous nutrients released into the soil by burning the stalks.

PLANTING: Farmers originally planted the seeds on mounds but these were turned into ridges under colonial rule to lessen the problems of soil erosion. The object of both systems is the same, which is to accumulate a greater depth of top soil by drawing it together and thereby offering the young plants a better environment in which to develop. The second advantage is that during the particularly wet periods which often occur during January the maize roots get some relief from water-logging by being above the level ground which is saturated.

Plant spacing: Maize seeds are planted on top of the ridges with the first good rains. 25 years ago they would have been planted one metre apart with legumes and pumpkins in between. With declining farm size farmers have focussed on increasing the production of maize and have increased the population of that crop at the expense of the legumes. Recent surveys have shown that intercropping is down from $75 \%$ of farms to $25 \%$ (NSO, 2010). Unfortunately the radical change from wide spacing which embodied many years of farmer experience has been replaced with a density of plant 
population which is unrelated to the nutrient content of the soil. The socalled "Sasasakawa" system which promotes a plant population of 48,000 is based on a fertiliser application of $96 \mathrm{~N}$ and $40 \mathrm{P}$ per hectare at which rate the spacing of the plants is reasonable The same population is now being advocated for plots with worked out soils and with either little or no additional fertiliser. The result is a crop of poorly developed plants many of which do not even carry a cob because of the paucity of nutrients in relation to the plant population. Research to identify optimum maize populations under poor soil conditions was conducted for three successive seasons by the excellent team of German agronomists working in the adaptive research section of Liwonde ADD. They established trials on a number of farmers' fields all of which were on typically worked out soils. They applied $26 \mathrm{~N}$ per ha and used three populations: 37,800, 27,700 and 20,800. At the end of the three years they reported (Liwonde, 1988) "At all sites in all seasons the two lower populations always out-yielded the highest population with the middle level consistently giving the highest yields". It would be a service to farmers if such research could be repeated so that appropriate advice could be given to farmers which linked maize plant populations to nutrient availability. This would replace the current blanket recommendation developed under levels of fertility seldom available to the majority of small scale farmers.

AFTERCARE: Like timely planting, early weeding is crucial to the achievement of a good crop and repeated surveys have shown that farmers are well aware of this and a journey through the country two to three weeks after planting will reveal a whole population involved in that task. The challenge which farmers face is that all too often it rains persistently in the period when the weeding should be carried out. Most farmers practicing conventional tillage carry out a second weeding. After that weeds are permitted to grow and are later buried and provide an additional source of organic matter to the soil. Herbicides, which overcome the problems of a wet weeding period, have proved to increase yields substantially in a wet year. Their application requires skilled supervision and the funds for the purchase of sprayers and chemicals, and the great majority of farmers have access to neither of these.

CROP NUTRITION: The third crucial factor determining maize yield is the availability of plant nutrients (Figure 4 and Figure 5). Most Malawian soils are deficient in nitrogen and unless the farmer can rectify this deficiency no amount of skilful husbandry will result in a reasonable yield. Few families own significant numbers of farm animals so they cannot use manure as a 
source of nutrients. It has been estimated that all organic sources of plant nutrients (manure, compost and leguminous plants) return an average of $8 \mathrm{~kg}$ of nutrients per hectare per year in Malawi (World Bank, 2004; Section 2.35). This is totally inadequate to meet the needs of the crop and farmers are dependent on inorganic fertiliser to make up the deficit. The importance of adequate plant nutrition is highlighted in a year when the climate includes periods of stress. In the 2015/16 season there were gaps in the rainfall of two weeks or so. The well-fed maize crops of wealthier commercial farmers and smallholders produced bumper yields in response to the absence of waterlogging and the increased amounts of sunshine. Poorly nourished plants were severely stressed by short periods of dryness and gave low yields so that the country was forced to make major maize imports. In neighbouring Zambia with less impoverished soils and more fertiliser available to farmers the country enjoyed its best maize harvest ever despite having the same climatic conditions as Malawi.

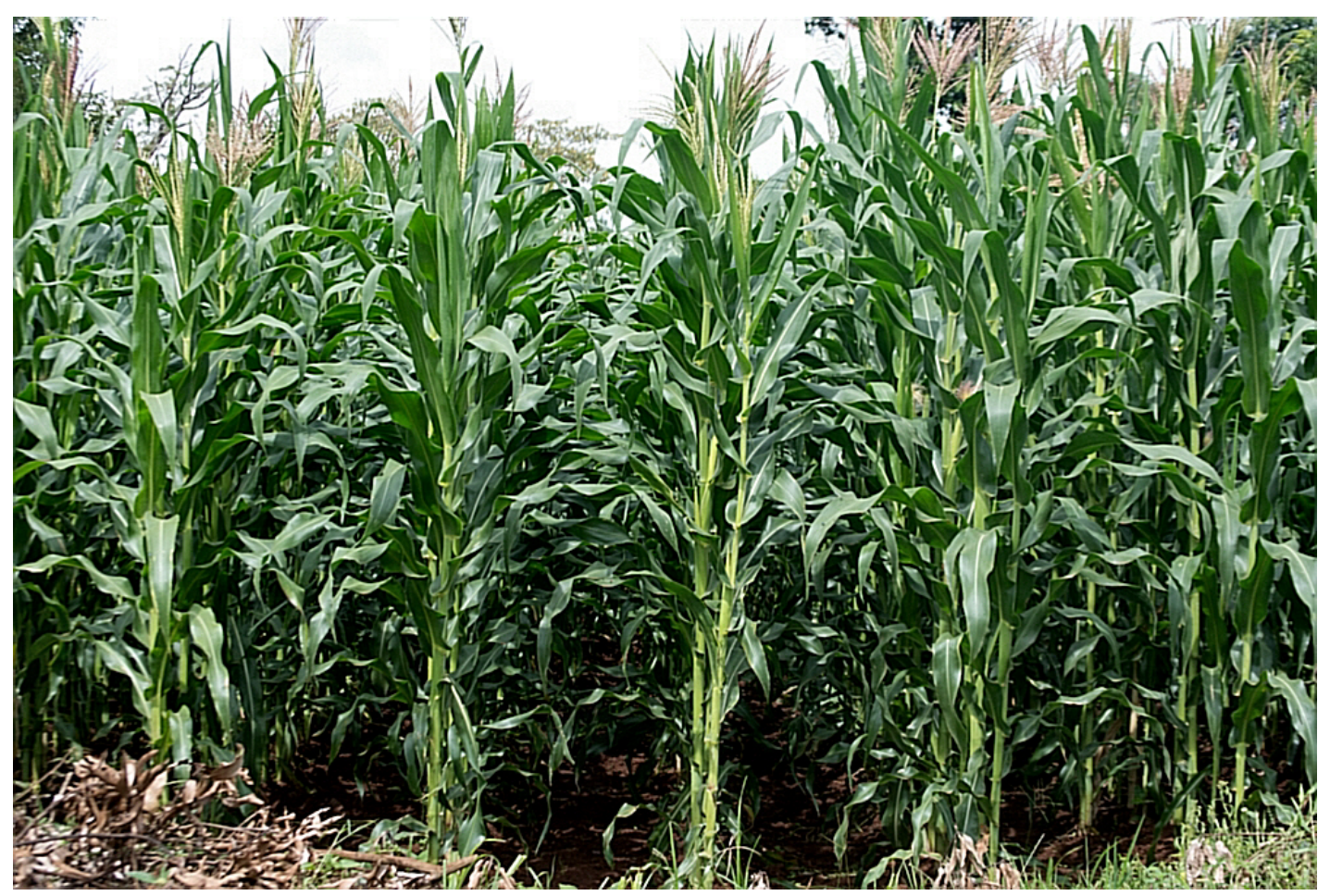

Figure 4. What the crop should look like 


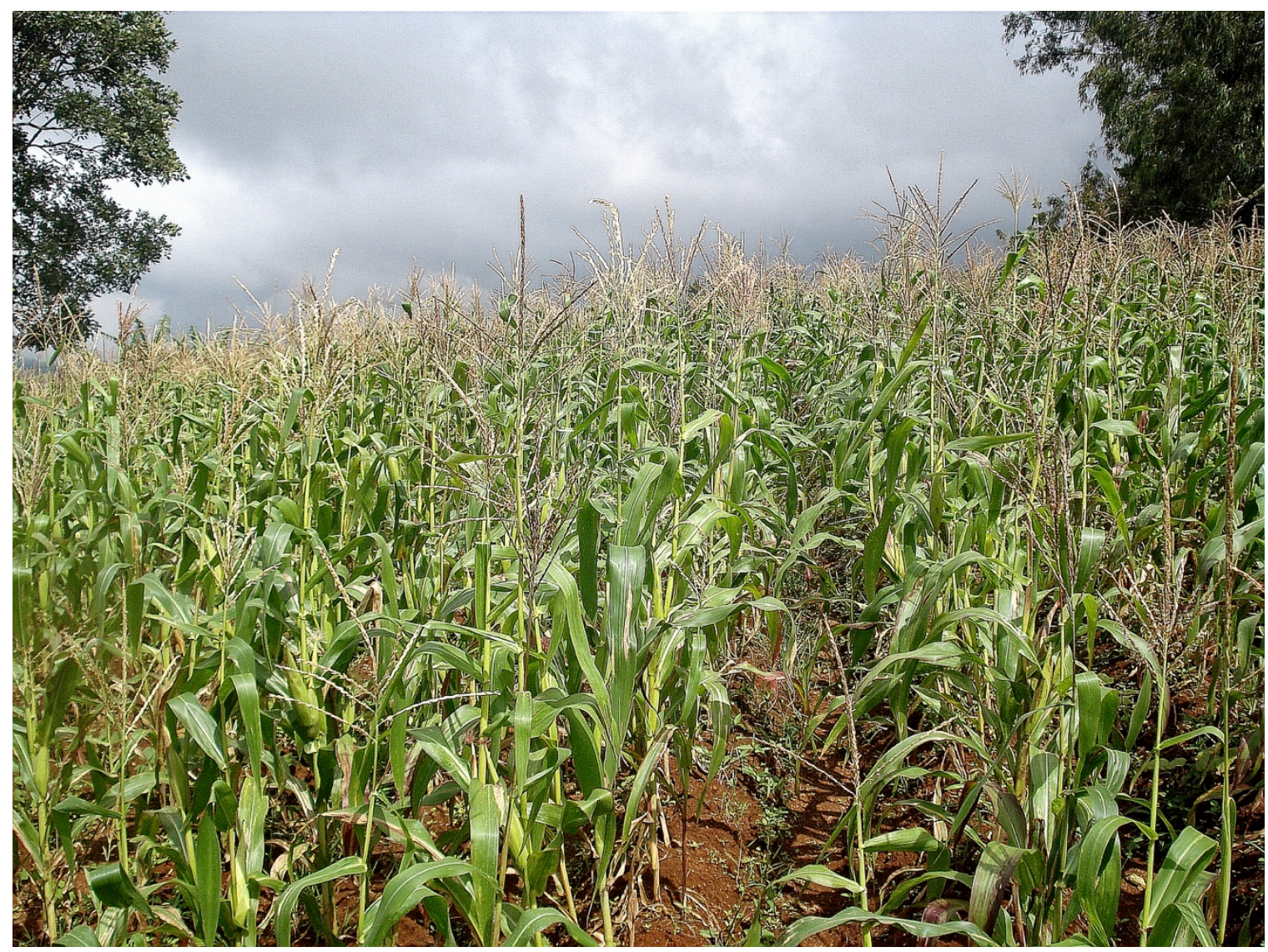

Figure 5. Typical of an over-crowded nitrogen-starved crop.

YIELD. The National Census of Agriculture records an average national yield of 1,384 kg per hectare for local maize and 1,915 for hybrid (NSO, 2010), Table 3.15). These figures mask wide variations as smallholders with exhausted soils and no access to fertiliser obtain 400 to $800 \mathrm{~kg}$ per hectare (Liwonde, 1982) while those with less stressed soils and adequate fertiliser can expect to get 4 tonnes per hectare (One Acre Fund, 2014). Unfortunately few farmers can gain access to the necessary amounts of fertiliser to achieve such a yield. Commercial farmers with well preserved soils, plentiful fertiliser and high quality seed aim to obtain 5 to 6 tonnes per hectare according to the season. The issue of plant nutrition is so crucial to an understanding of smallholder farming in Malawi that it will be allocated a separate section.

STORAGE: For most of the period in which maize has been the dominant staple in Malawi the crop was harvested in June when it was completely dry and then stored in the sheath in large open weaved "baskets" called 
Nkhokwe. Cobs were taken out as needed and stripped and shucked. With the breakdown in rural security which started in the mid 1990s, the system has changed completely. For fear of theft the maize is harvested at the end of the rains with a moisture content of $17 \%$. It is shucked straight away and stored in the house in sacks because Nkhokwe are too vulnerable to theft. Attempts are made to dry the grain on mats on sunny days but there is widespread risk of aflatoxin being produced on such grain with long term adverse consequences for human health.

\section{SORGHUM}

This is a minor crop in Malawi occupying one per cent of the total cropped area (NSO, 2010), Table 3:11). Outside of the driest areas in the Rift Valley it is grown almost exclusively for beer making. Typically it will be mixed in small quantities with other crops rather than being grown in pure stand. Sorghum was domesticated in the drier areas of Ethiopia which are substantially drier than Malawi. It is capable of surviving mid season droughts more efficiently than maize. On poor soils with adverse climatic conditions it will out-yield maize, but its potential yield is much lower. The reason for this derives from the balance in both crops between the weight of the stalk and the weight of grain, known as the harvest index (Figure 6). In sorghum the proportion of grain in the weight of the mature plant is $23 \%$ while in maize it is $46 \%$. This is the main reason why farmers in Africa who live in areas with adequate rainfall to produce a maize crop have abandoned sorghum. A second reason is the way in which the crop responds to fertiliser. Because much of the nutrients are used to develop stalk rather than grain sorghum gives a far lower response to added fertiliser than maize. There are much shorter and higher yielding sorghums which have been developed. These all have tightly packed seed in their panicles as compared to the open pattern of those in common use in Malawi. These compact heads are highly susceptible to fungus attack if there are moist conditions at the time the crop is maturing which is typical of Malawi. Large quantities of seed of a short quick maturing sorghum were distributed to tens of thousands of farmers after the El Niño event of 1992. The crop was planted but with a wet March in 1993 virtually no seeds were harvested and nobody tried the crop for a second season. Recent releases of short stemmed open panicled and palatable sorghums from ICRISAT are showing favourable results under trial conditions. Elsewhere in Africa these would be subject to serious losses to birds but bird populations are now so low in Malawi that this may not prove so serious a problem. These sorghums will not have the yield potential of maize but may prove useful in some future situations. 
There is a move among the donor community in Malawi to try and replace maize with sorghum as the main staple grain. Unless the average rainfall drops below $550 \mathrm{~mm}$ over large areas of the country there seems little likelihood that farmers will make this choice.

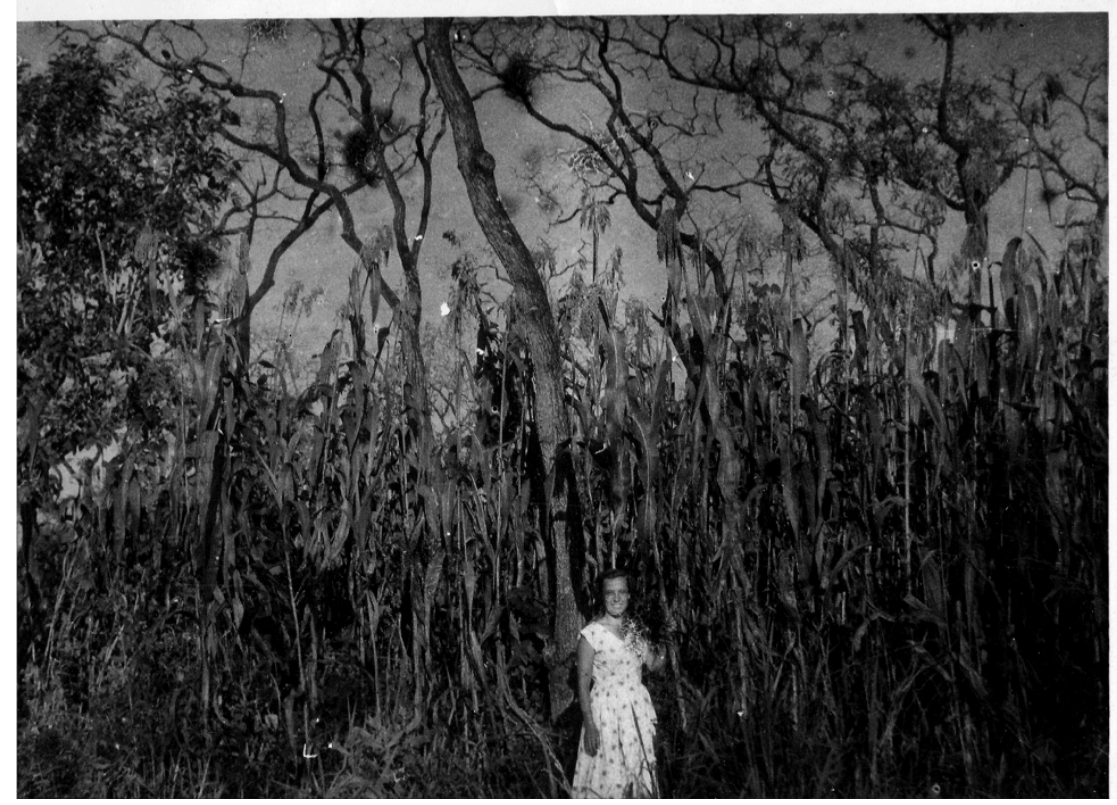

Figure 6. A tall sorghum crop has a low harvest index due to its relatively high amount of stover biomass and its relatively low amount of grain biomass.

\section{MILLETS}

Two species of millet were traditionally grown by Malawian smallholders, finger millet (Eleusine coracana) in the wet areas and bulrush millet (Pennisetum glaucum) in the driest areas. The former is a highly nutritious grain which was a dominant staple in the wetter areas of Africa. In 1970 in Uganda finger millet was the dominant grain staple occupying almost ten times the area allocated to maize (Jameson, 1970). It is a comparatively low yielding crop with a particularly high demand for labour at all stages of production and so to-day, despite its nutritious value and palatability, it has been almost totally replaced by maize. In Malawi only small quantities of the crop are now produced and used as a malt for beer making. It is most unlikely to return as a significant staple.

Bulrush millet was domesticated on the edges of the Sahara and is adapted to grow in areas with high temperatures (over 30 degrees) and with a pronounced dry period at the time of ripening. Like the tight headed sorghums it is susceptible to serious fungus infestation in the grain heads if the weather is wet when the crop is ripening. The crop is likely to remain 
popular in the dry, hot areas of the lower Shire but is unlikely to spread on to the Plateau unless there is a quite dramatic change in the climate. The millets currently occupy $0.07 \%$ of the cropped area (National Census of Agriculture, Table 3.11 (NSO, 2010)).

\section{RICE}

Although rice is obviously a food crop it is in fact treated as a cash crop by the majority of growers in Malawi. The climate is not wet enough for upland rice and the crop in Malawi is grown under some form of irrigation. There are a number of formal irrigation schemes mostly originally funded by donors on which rice is the dominant crop. In a number of these, establishment costs were particularly high and as farmers do not pay for their water they need continuing external support so that it is difficult to make an accurate assessment of the true cost of this form of rice production. Elsewhere smallholders use small areas of impeded drainage or water diversions on which to grow the crop. The area of this informal production is heavily dependent on the amount of rain which falls during a particular season. The crop is grown by a small minority of farmers and occupies $0.018 \%$ of the cultivated area in the country (National Census of Agriculture (NSO, 2010), Table 3:11).

\section{LEGUMES}

\section{GROUNDNUT}

This crop used to be the fourth major export crop for Malawi reaching a peak of $11 \%$ by value of all exports. The variety Chalimbana was in demand by the confectionary trade in Europe because of its exceptional quality. Towards the end of the 1980s the European trade found an alternative nut of similar quality but which did not split into two when blanched (the skin was removed). The demand for Chalimbana collapsed and before an alternative could be identified the EU had imposed limits on the aflatoxin levels on groundnuts which they would tolerate, with which Malawi finds it difficult to comply. In consequence the overwhelming proportion of the crop is now grown for local use with small quantities of carefully selected nuts being exported.

Chalimbana is still the favourite nut for confectionary use but the less palatable variety CG7 now occupies a larger area of land nationwide because of its resistance to the serious disease of rosette which can cause a significant loss of yield in susceptible varieties. The crop used to be grown extensively as an intercrop in maize but is now mostly grown in small plots 
in pure stand (Figure 7). The National Census of Agriculture records that the great majority of groundnut plots are of less than 0.5 ha (Table 2.57). The main constraint on yields is fungal disease of the leaves and breeding has not yet produced strong resistance to this challenge (Singh, Mehan, \& Nigam, 1997).

The crop fixes significant amounts of nitrogen and benefits the following crop. Research trial results on farmers' fields have shown a $28 \%$ increase in yield of maize following groundnuts as opposed to maize following maize (Liwonde, 1988). However, as the crop only occupies 5.8\% of the total smallholder crop area, it is not able to play a major role in restoring national soil fertility.

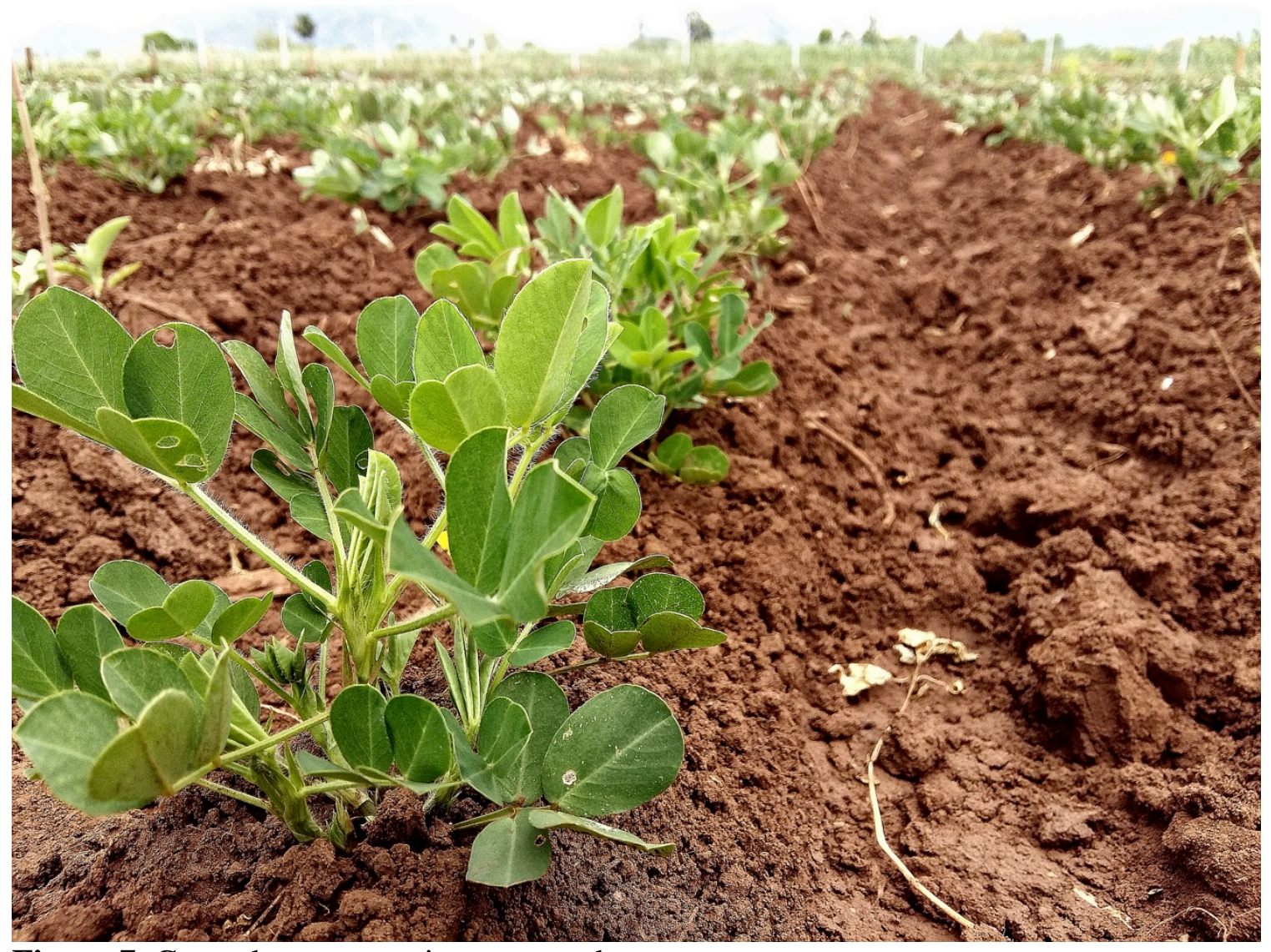

Figure 7. Groundnuts grown in pure stand. 


\section{SOYABEAN}

This is a minor crop in Malawi but has several valuable features. It contains the richest source of quality protein among cultivated crops, has a high oil content, is higher yielding than other beans and is capable of fixing more nitrogen than other beans. Its wider use would make a significant contribution to human nutrition, particularly children, and to soil fertility. The main reason for the slow rate of adoption of the crop is the fact that the seeds need to be roasted before they can be used as food. This is because soya contains a factor which inhibits protein digestion which is not destroyed by boiling but requires higher temperatures. A number of attempts to popularise the crop have failed to provide women with this essential teaching and they have found the bean unpalatable and indigestible. The majority of soya beans grown worldwide are short, quick maturing and fix little nitrogen. The seed needs to be inoculated with bacteria and this technology has been shown not to be practical for large numbers of farming women living in remote areas. These varieties are bred for combine harvesting and are not the most suitable for smallholders. There is another group of soya which consists of tall plants which produce seed over a protracted period, do not need inoculation, but fix large amounts of nitrogen. The first variety of this type which was brought into Malawi in the early 1990s was called Magoye and was bred in Zambia. It proved popular and production was sufficient to justify establishing three plants in the country to process the crop into a children's fortified food. It was shown to fix up to 40 $\mathrm{kg}$ of nitrogen per hectare with a striking impact on the following maize crop. Unfortunately a number of donors brought in a range of material from around the globe without proper screening and introduced Asiatic rust into Malawi. Magoye proved to be susceptible and was abandoned. Research at Chitedze has focussed on producing the same type of indeterminate soya beans which are also resistant to the rust (Figure 8). The first of these to be released is called Tikolore (TGx1740-2F) and deserves to be widely popularised with the necessary training in its preparation both as an everyday food and as a weaning food for children. It is not the variety for commercial growers involved with mechanised production. 


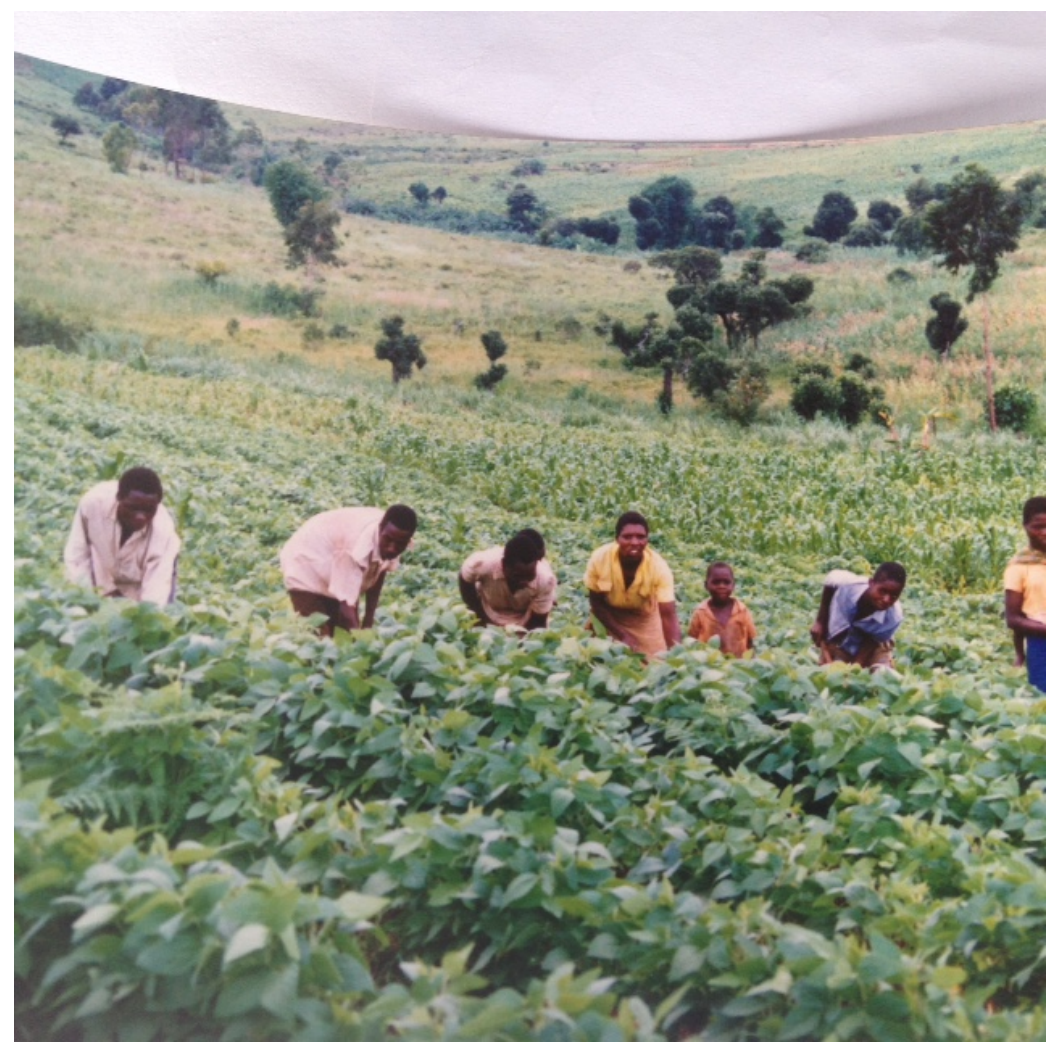

Figure 8. Indeterminate soybeans tall and dark green.

\section{PIGEONPEA}

This is one of our most useful plants. It produces food, cash, soil fertility, firewood and breaks through hard pans under the soil. It was domesticated in India but arrived at an early date on the shores of East Africa. It received its English name in Barbados in the $17^{\text {th }}$. Century when the people discovered that it was good food for pigeons which is now a totally insignificant part of its use but the name has stuck. Like soya there are two broadly different kinds of pigeon peas in common use. They are determinate or short season varieties and indeterminate or long season varieties and it is crucial to appreciate the difference under Malawian conditions. The pigeon peas which have been traditionally grown in this country are long season ones. These take between seven and ten months to mature and produce multiple generations of flowers (Figure 9). It is this feature which is important for smallholders. The crop is attacked by a range of flower eating insects which are capable of stripping the plant of all its flowers. The long term pigeon peas continue to produce more flowers and finally the pests disappear and the plant is then able to set a satisfactory crop. The short term varieties produce just one large flush of flowers and if these are all destroyed by pests the farmer will get no crop. If farmers are supplied with the seeds of a 
determinate variety it is crucial that they are also equipped to spray the crop, usually three times, to protect the flowers. There have been well meant distributions of high yielding quick maturing determinate pigeon peas by donors in the past without the necessary insecticides, and farmers have harvested nothing.

The traditional Malawian long season pigeon peas which required nine or ten months to mature could only be grown in a microclimatic area in Blantyre and Machinga districts which received mist and drizzle in June and July (Chiperone) which supplied the moisture necessary to fill the seeds. Research has now produced an indeterminate variety which matures in June and which can therefore be planted anywhere in the country apart from the hottest and driest areas.

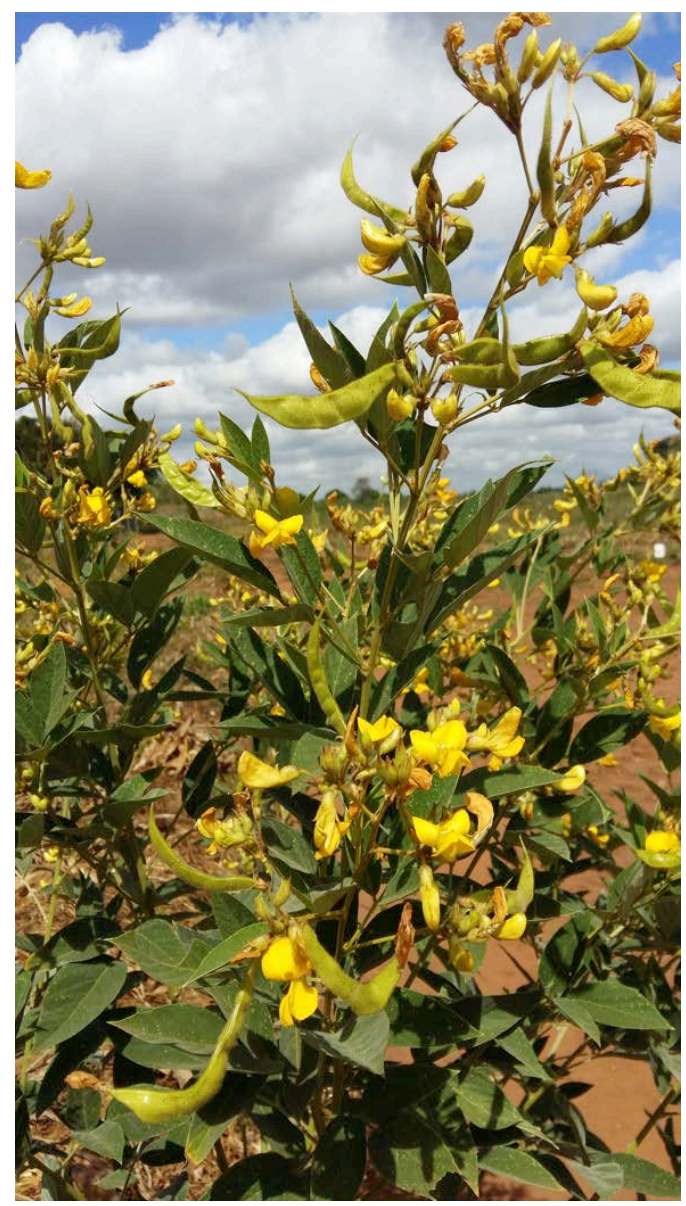

Figure 9. Pigeon pea at flowering stage. 
The advantages of the crop are (1) that it is well suited to intercropping with a grain crop. Its early energies are devoted to root growth so it offers minimal competition to the grain and then grows rapidly once the maize has been harvested. (2) Its roots associate with a range of rhizobia in Malawi's soils so that it develops nodules and fixes nitrogen with no need for inoculation. (3) It fixes a lot of nitrogen which accumulates in the leaves which fall at maturity and enrich the soil for the following crop. After a pure stand of the crop up to $40 \mathrm{~kg}$ per hectare of nitrogen become available for the following crop (Kumar Rao, 1990; p. 247) although for a mixed crop with a lower plant population the amount will be proportionately less. (4) Unlike smaller legumes and grain crops, pigeon pea has a powerful woody tap root which can penetrate as far as two metres into the soil (Reddy, 1990; p. 54). This not only allows it to grow strongly into the dry season but it can break through compacted soil layers and open up the soil for other crops with weaker roots. (5) There is a well developed market for the crop in Malawi which is processed into dhal for export to India (6) The woody stems make excellent firewood which will become an increasingly valuable asset as other sources of fuel become scarcer.

The crop is thoroughly familiar to farmers in its traditional heartland but there are many smallholders in other areas who are unaware of the introduction of the new varieties which can be much more widely grown. This is a crop which deserves much more attention now that it can be widely grown. Promoting its spread into new areas provides an excellent opportunity for a valuable project initiative.

\section{BEANS}

Haricot beans (Phaseolus vulgaris) are an important food source in Malawi rendered more so by the decline in the fishery industry as a source of protein. The crop is of South and Meso-American origin, from areas of comparatively high rainfall. It is not drought resistant and yields poorly in areas with high temperatures (Acland, 1971). Beans therefore do best in Malawi in higher altitude areas with dependable rainfall. Unfortunately this legume either does not nodulate or has small nodules which fix little nitrogen. They therefore do not thrive on soils deficient in nitrogen nor do they contribute any significant benefits to the following crop. In trials in Malawi it has been consistently found that beans respond positively to applications of phosphate even in areas where maize shows no such response (Chitedze). 
Apart from soil fertility it is disease which provides the main curb on bean yields in Malawi and it is therefore on resistance to diseases and pests that most research in the country has been focussed. This has sought to use available resistant genes in the species to increase the resistance of lines which are otherwise acceptable to both farmers and consumers. There have been successes in this initiative but the spread of this superior seed has been slow in the absence of a major national programme to multiply and popularise this material.

\section{ROOT CROPS}

The place that root crops occupy in the smallholder sector has been confused for a number of years by the official production figures which are provided by the Ministry of Agriculture. These suddenly changed dramatically in the 1990s. In 1991 the total production of root crops was recorded as 227,115 tonnes. Five years later it had grown to 1,237,440 with no change in varieties or climate. By the end of the decade production was reported to be 6,280 585 tonnes in a year when the maize production was 1,713,004 By this time it was claimed that root crops were the dominant food of Malawi and that every man, woman and child in the country was consuming 4,286 calories per day. These claims were not borne out by data on diet and welfare nor reflected in the experience of the majority of the population. This major leap in agricultural production had an impact on the national GDP and so the IMF seconded one of its experienced statisticians (Russel Freeman) to the National Statistics Office for two years to generally check on the GDP figures. In his final report on root crops (Freeman, 2000) he estimated that the actual cassava production was $10 \%$ of the official figures and that sweet potato production was $9 \%$ of the published figures. His figures were based on the reports of large numbers of field assistants, discussions with a range of agronomists and on the consumption data provided by the Integrated Household Survey.

His report had no significant impact on the official position and the National Agricultural Census figures indicate that the official figures for cassava production were overstated by sevenfold and for sweet potatoes the over estimate of production was reckoned to be fourteen fold. These notes will be written on the basis of cassava and sweet potatoes being useful minor crops and not a dominant part of the Malawian diet. 


\section{CASSAVA}

This crop was domesticated in the wet tropics of South America and although it is tolerant of drought it does not give of its best in a climate with a long dry season and low night temperatures in the middle of the growing year. In Malawi half of the crop is grown in pure stand, mostly in the North and Centre (National Census of Agriculture (NSO, 2010), Table 2.56) the rest is inter-planted in maize fields which is most common in the South. The pure stand crop is planted from cuttings in land that is usually prepared after the work on maize has been completed. It is then allowed to grow into the following wet season and is harvested as required for home consumption or sale. In the other $50 \%$ the cuttings are pushed down into the maize ridges after the first weeding is completed. The crop is then shaded by the maize in its early stages of growth and when the grain crop is removed the rains have ceased and the cassava has to deal with dry conditions until it is harvested, while immature, in September and October so that the land can be prepared for the next maize planting. The whole crop is harvested at once and markets are flooded with small cassava roots which are usually smaller than sweet potatoes. The crop is light but has been obtained with a minimum of incremental labour.

YIELDS: For the pure stand crop the National Census of Agriculture gives a figure of 5.12 tonnes per hectare of wet roots. This is obtained from a given area of land over two seasons so the production per year is half of that. This yield is in line with the yields obtained from the two most common "local" varieties on 27 trial plots at research stations across the country. The average yield for all the plots was 9.5 tons of fresh roots per ha (Kumbira, Benesi, \& Ngma). The World Bank and FAO use a factor of 0.6 to convert trial results into farm level yields which would give a yield of 5.7 tons. There are few surveys of the mixed crop because the plants are often scattered quite widely through the maize crop making it difficult to obtain an accurate estimate of yield for the whole cropped area. Those surveys which do exist give the yield as two tons per hectare but these are from fields in which cassava was uniformly planted throughout the whole of the maize crop (Liwonde, 1988). PLANT NUTRITION: There is a widely held belief that cassava removes fewer nutrients from the soil than maize to produce the same number of calories. This is not the case but it is the balance of nutrients which is of importance as shown by Table 3 . 
Table 3. A comparison of major nutrient use between maize and cassava

\begin{tabular}{|l|c|c|}
\hline & Maize & Cassava fresh roots \\
\hline $\begin{array}{l}\text { Number of kcal } \\
\text { required by 4 persons } \\
\text { each year }\end{array}$ & $3,212,000$ & $3,212,000$ \\
\hline $\begin{array}{l}\text { Weight of crop needed } \\
\text { to supply the above }\end{array}$ & $992 \mathrm{~kg}$ & $2,946 \mathrm{~kg}$ \\
\hline Removal of N kg & 22 & 14.5 \\
\hline Removal of P kg & 3.6 & 2.9 \\
\hline Removal of K kg & 10.8 & 18.8 \\
\hline Total removed & $\mathbf{3 6 . 4}$ & $\mathbf{3 6 . 2}$ \\
\hline
\end{tabular}

Source FAO tables.

It is because of its lower demand for nitrogen that there have been efforts by donors to make cassava the main staple of Malawi. These initiatives provoked concern among those involved with issues of human nutrition. Cassava roots contain less than 1\% of protein and no Vitamin B (Platt, 1945), both of which are essential to human health. There has been minimal response by farmers to these initiatives and production per capita which was $35.6 \mathrm{~kg}$ per year in 1984 had declined slightly to $31.3 \mathrm{~kg}$ in 2007 (National Census of Agriculture (NSO, 2010), Table 3.13). The crop occupied 2.8\% of cultivated land in 2007 (National Census of Agriculture (NSO, 2010), Table 3.12). For most smallholders in Malawi cassava is likely to remain a minor, useful supplement unless there are far greater changes in the climate than those which are now predicted.

\section{SWEET POTATOES}

This is another useful minor crop grown by large numbers of people on small areas of land. Typically it is grown on a single ridge around a maize field or on a few contiguous ridges in a corner of the farm. The exception to this situation is provided by people who have gardens with impeded drainage (dimbas) who grow the crop for cash. The National Census of Agriculture estimated that the crop occupies 2\% of the total farmed are (NSO, 2010, Table 3.12) with a yield of 2.6 tons per hectare (NSO, 2010, Table 3.17). The main constraint on yields is the availability of planting material early in the rainy season. The crop is planted from soft stem cuttings and these do not survive the dry season. Farmers then wait for tubers from the previous season to sprout and grow and it is often late February or March before the crop is planted which results in low yields. It 
is only those who have dimba gardens who are able to plant on time. It is possible to greatly increase the availability of planting stems by growing a small irrigated area on simple frames made of sticks and reeds over which the plants climb. This system will provide much more planting material than plants growing along the ground.

The crop has sometimes been proposed as an alternative staple to maize. This ignores the fact that it is eaten fresh and is only available for the great majority of growers from May until early October. It is therefore bound to continue its current role as a useful supplement but not as a staple crop.

\section{SECTION 5 CROP DIVERSIFICATION}

An earlier section explained the good reasons why Malawian farmers had selected maize as their dominant staple crop, and yet for the past quarter of a century there has been a steady demand that they should diversify out of maize. Most of these calls have been unaccompanied by any suggestions as to what alternative crops they should grow and the few proposals that have been made for starchy staples (sorghum, millet, cassava and sweet potatoes) have been ignored by farmers for reasons covered in the description of those crops. A more understandable call for change comes from those concerned with nutrition and soil fertility who would like to see more legumes, especially groundnuts and soya beans, in farmers' fields. These leguminous crops have, by definition, a lower quantitative yield than starchy ones because of the extra energy required to manufacture protein and oil. In consequence farmers will only allocate scarce land to them once they have been enabled to increase their maize yields and so release land for lower yielding crops. The first major diversification project after Independence focussed on greatly increasing groundnut production. Staff realised that to release land for groundnuts they would have to increase maize yields and so they started with a programme of popularising hybrid maize and fertiliser and followed that with the groundnuts. The strategy worked well and Malawi became a significant exporter of confectionary nuts. This success provides the crucial lesson to those who would have farmers allocate more land to legumes now. Unfortunately that lesson is ignored and the opposite strategy has been adopted. Current policy is to reduce maize production by limiting farmer access to the essential inputs of seed and fertiliser which determine maize yields. Any decline in maize yields will stimulate farmers to plant a larger area to that crop and ensure that there will 
be no rapid growth in the adoption of desirable legumes. The path to diversification has to be drawn by ensuring families of the adequacy of their main staple when they will then have the freedom to allocate part of their scarce land to other lower yielding but more nutritious crops. Unless this need to increase maize yields as a path to diversification is appreciated and implemented the failure of attempts to diversify farmers' food crops ill continue to face the failure of the past quarter of a century.

A different path to dietary improvement lies with fruit trees and vegetables which require small areas of land and yet are a rich source of vitamins, minerals as well as calories. There have been virtually no major projects aimed at these crops. Grafted mangos and avocados are potentially rich sources of both food and cash. Guavas and pawpaws can boost the intake of vitamins and minerals and yet little is done to encourage their adoption. Farmers now plant seeds of mangos and avocados which take years to come into production and whose quality is unknown whereas grafted trees start to bear far more quickly and can produce both better quality and higher yields. Anyone who has tried to popularise these trees will know how difficult it is at present to obtain even 5,000 trees, let alone the number that is actually required. Fruit trees offer a worthwhile opportunity for diversification and dietary improvement independent of maize. It needs to be a serious initiative and not an insignificant add-on, but which employs adequate professional staff who are essential both in the nurseries and for the fieldwork. There is also scope for improving on the supply of vegetables for home consumption and sale. Wet season gardening around villages is plagued by free ranging chickens and only those who are prepared to invest considerable labour in fencing can have much success. Dry season vegetable production in dimbas is much more successful but it is confined to the fortunate minority who have access to such areas. The majority can be helped by harvesting just a fraction of the millions of litres of water which run off the land every year. Only on absolutely flat land is it not possible to collect adequate run-off water for a productive vegetable garden. Fortunately, all that is needed on the red lateritic soils which are dominant in the country is to dig a pit to catch the water. If the bottom is puddled by stamping after the first rain it will not leak and there is no need for a lining. A pit 4 metres wide and 2 metres deep will store enough water for a decent sized vegetable garden if the watering is done by hand and not with a pump. Several NGO's have successfully established such water harvesting systems and yet most of the water which runs off the land is not stored, and vegetable production is minimal for many families in the dry season. In India such pits, called 
"tanks" are the basis for irrigation for thousands of families. There is no reason why the same should not be true in Malawi. Dams require special geographical situations. Pits can be made in far more situations and, unlike poorly constructed dams they cannot break. Once again this is an opportunity to positively diversify the diet of large numbers of people which is being ignored. As with a serious fruit tree planting in initiative this needs experienced staff and adequate funding, but it is a way in which dietary diversification can be achieved without waiting for broad national policies to deal with the issue of maize production.

\section{SECTION 6 \\ INCREASING SMALLHOLDER FOOD PRODUCTION}

There is understandable concern about future changes in the country's climate which could have an adverse impact upon national and household food security. It is unfortunate that similar concern is not expressed about the 'nitrogen drought' which has seriously affected Malawian smallholders in recent years and led to increasing numbers of people being dependent on food relief supplies. The 2015/16 season provided a good example of this fact. It was marked by a freedom from waterlogging and with an increased amount of sunshine. As a result maize farmers in the region experienced a bumper harvest. Zambia enjoyed its biggest maize crop ever recorded, Mozambique had a small surplus and declining maize prices and Malawian farmers, both commercial and more prosperous smallholders who could afford adequate fertiliser also enjoyed particularly high yields of maize (Table 4).

Table 4. Maize production in three countries 2016.

\begin{tabular}{|c|c|c|c|c|}
\hline COUNTRY & $\begin{array}{c}\text { PRODUCTION DEMAND } \\
2015 / 16\end{array}$ & $\begin{array}{c}\text { SURPLUS } \\
\text { DEFICIT }\end{array}$ & $\begin{array}{c}\text { PRICE } \\
\text { CHANGE }\end{array}$ \\
\hline MALAWI & $2.776 \mathrm{MN}$. & $3.750 \mathrm{MN}$. & $-0.974 \mathrm{MN}$ & $31.6 \%$ \\
\hline MOZAMBIQUE & $1.5 \mathrm{MN}$. & $1.45 \mathrm{MN}$. & $+0.05 \mathrm{MN}$ & $-3.3 \%$ \\
\hline ZAMBIA & $3.667 \mathrm{MN}$. & $2.50 \mathrm{MN}$. & $+1.167 \mathrm{MN}$ & $-2.1 \%$ \\
\hline
\end{tabular}


Unfortunately the amount of subsidised fertiliser made available to smallholders had, on a per capita basis, been cut by $60 \%$ from its 2007/08 level. As a result the majority of Malawian smallholders had fields of nitrogen starved plants with a poorly developed root system which were unable to deal effectively with a couple of weeks gap in the rains and so they enjoyed none of the high yields achieved by their wealthier neighbours and those in adjacent countries (Figure 10). As a result of this restriction of access by farmers to the essential plant nutrients that they need the country is faced with the large cost of providing supplementary food to 6.5 million people, part of which will be imported from Zambia which had the same weather conditions as Malawi but much more generous availability of fertiliser.

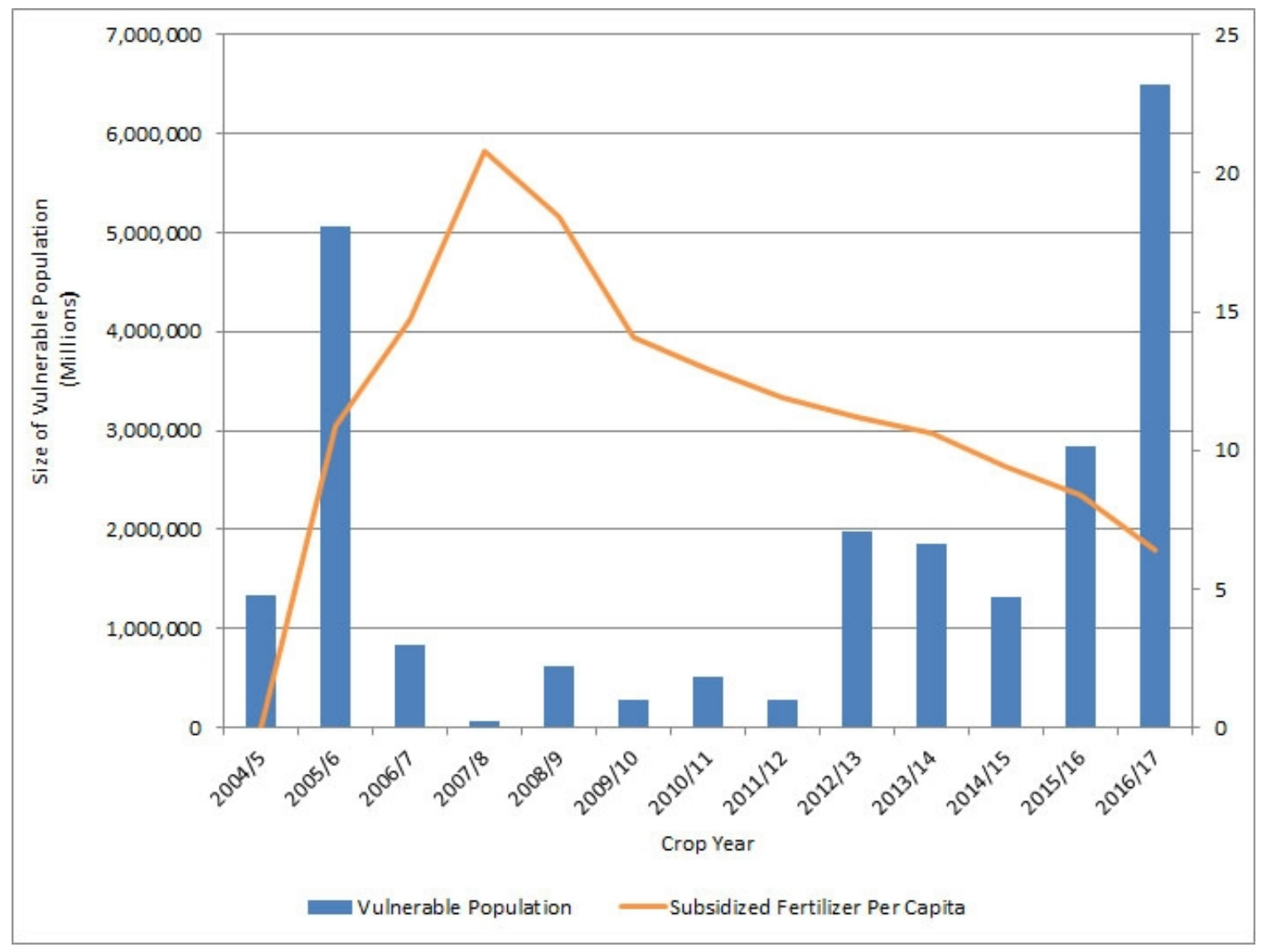

Figure 10. Amount of subsidized fertilizer per head $(\mathrm{kg})$ and size of vulnerable population (millions) in Malawi for the last 12 years. Author's calculations are based on various FEWSNET and World Bank reports for the vulnerability figures and on the Annual Evaluation of the Agricultural Subsidy Programme in Malawi by Dorward, Chirwa et al. and funded by DFID for the subsidy figures. The population estimates are from the Population and Housing Census figures produced by NSO (NSO, 2008). 
The reason given by the government for reducing the amount of subsidised fertiliser made available to farmers is that it is not affordable. This does not tally with the fact that the cost of feeding 6.5 million people is estimated to be over $\$ 300$ million with which the amount of fertiliser which was subsidised could have been trebled, giving the country a substantial surplus of maize like its neighbour.

Predicting future weather patterns is extremely difficult but we can be quite sure that both farmers and agronomists are correct in predicting that the "nitrogen drought" which currently afflicts the country will only get steadily worse if the current policy of regularly reducing farmers' access to plant nutrients is maintained. Unless policy makers can grasp the truth known to farmers and experienced agriculturalists that "starving plants result in hungry people" then food aid will be a regular feature of the Malawian scene and the country's soils will become steadily more impoverished.

\begin{abstract}
ALTERNATIVES TO FERTILISER: The past 25 years have seen major efforts made to counteract the shortage of plant nutrients in the country's soils without the use of expensive inorganic fertiliser. These have included "organic" strategies using animal manure, compost and leguminous crops to replace the nutrients lost to cropping. Earlier parts of these notes have indicated why such strategies are capable of maintaining soil fertility in the long term to just a small part of the rapidly growing number of smallholder farmers.
\end{abstract}

Agro-forestry was seen as a possible "silver bullet" and a great deal of effort and money was invested in promoting this approach in the 1990s. Leucaena alley cropping had been tried and failed but three year fallows with Tephrosia were giving positive results in Eastern Zambia. A major drive was made to popularise the inter-planting of Tephrosia in Malawi and many tons of seed were distributed to farmers. It was fully appreciated that three year fallows were out of the question in Malawi but trials had shown that burying of the green material from Tephrosia which had been growing for eight months could raise the yield of the following maize crop by $20 \%$. In the event farmers found that the amount of incremental yield did not compensate for the extra work and the loss of intercrops and there was no uptake of the technology by the tens of thousands who tried it. ICRAF has spent 25 years trying to popularise the establishment of lines of Gliricidia sepium in between the maize in Zomba district but there has been minimal spread of the technology. The big push to promote the spread of the 
indigenous tree Faidherbia albida in the 1990 s has borne some fruit with an extended area planted to the species each year but it occupies a small fraction of the agricultural land. Uptake is inhibited by the waiting period of ten years before any benefits are seen. Agroforestry proponents are yet to come up with a technology which will be successful in overcoming Malawi's nitrogen drought and hopefully they will keep up the search.

Conservation Agriculture was first promoted in a major drive funded by the European Union in 1996. Large numbers of Malawian smallholders were bussed to Zimbabwe to see the technology there and leading Zimbabwean proponents were brought to Malawi to initiate demonstrations across the country. This initiative 20 years ago has been followed by a large number of NGO's and government services propagating this combination of minimum tillage, mulching and crop rotation. The system faces two basic challenges in Malawi. Farmers who obtain yields of less than 1.5 tons of maize to the hectare get too little stover to mulch more than a small part of their farm to a depth which will suppress weeds and stop soil erosion. The second is that, as has been explained earlier, those farmers with typically small plots of land are unwilling to allocate half of it to a legume each year and therefore the system adds no nitrogen to the soil and so does not address the poor smallholder's most fundamental problem. For those with adequate sources of plant nutrients the system protects the soil from rain beat, increases moisture retention and over the long term reduces the loss of nitrogen from the soil by volatilisation. These benefits can only be realised when farmers have been helped to overcome their nitrogen drought. It is largely because of this fact that a survey funded by CISANET and carried out by Bunda College estimated that less than 1\% of smallholders in the areas surveyed in various parts of the country were adopters of Conservation Agriculture (Uleuk \& Chimungu, 2015).

It was because of the slow spread of these alternative technologies that he government in 2005 decided to follow the example of the rest of the world and subsidise fertiliser. To avoid a widespread leakage of expensive fertiliser across Malawi's lengthy borders the fertiliser was allocated to individual families through a system of coupons rather than having a blanket subsidy for all fertiliser. The plan was to provide at least $60 \%$ of the farming population with $100 \mathrm{~kg}$ of fertiliser at a $75 \%$ subsidy. The fertiliser was to contain $35 \mathrm{~kg}$ of nitrogen and $10 \mathrm{~kg}$ of phosphate plus $2 \mathrm{~kg}$ of sulphur. With modest levels of management this was expected to provide farmers with an extra $525 \mathrm{~kg}$ of harvested maize which was expected to close the food gap 
for a typical household and achieve their food security. At the national level the harvest was expected to be increased by some 900,000 tons, but the emphasis was on the household's welfare. The initial impact was striking and the proportion of the population requiring supplementary feeding dropped from $39 \%$ to $0.5 \%$ and remained at a low level for five years (see Figure 10). Then as the population rose rapidly so the government steadily reduced the amount of fertiliser it subsidised with the inevitable result that the number of people needing food aid returned to the earlier levels. The amount of fertiliser subsidised per head of rural population declined from $20.8 \mathrm{~kg}$ in 2007/08 to 9.4 in 2015 and with more cuts proposed for 2016. This policy does not just result in hungry people and the huge burden on the country of feeding millions of people it equally importantly means that across the country more nutrients are being taken from the soil each year than are being replaced so that the country's most important capital asset is being steadily degraded.

People ask why farmers cannot be "graduated" from the system and buy their own fertiliser. As explained above the small amount of fertiliser provided under Farm Input Subsidy Program (FISP) was enough to help close the food gap in a family and reduce the number of people requiring food aid. It does not provide a saleable surplus with which future fertiliser could be bought. Regular surveys of FISP revealed that only 18\% of recipients ever sold any maize (Chirwa \& Dorward, 2013). Given that the majority of Malawian smallholders are classified as living below the poverty line they are not in a position to buy fertiliser at commercial prices and so they can only gain access to the materials that they need to overcome the country's annual nitrogen drought if fertiliser is subsidised.

FISP has gained a bad name because of mismanagement, late seed and fertiliser deliveries and corruption. All of these issues need to be addressed but the failures of the system should not be used as an excuse for abandoning a strategy without which the country faces a future of declining agricultural production and soil fertility.

\section{SECTION 7 \\ IRRIGATION}

The sight of a country with a seven month dry season but blessed with the third largest lake in Africa prompts visitors to demand why Malawians are not using that water to irrigate their maize crop and increase food production. The answer is quite simple because the high cost of fuel makes 
pumping water uphill out of the lake and on to a comparatively low valued crop an uneconomical proposition and Malawian farmers are not keen on losing their money in that way. While the country has some significant lakes it has few sources of water running downhill which could be used for gravity fed irrigation. Various mechanised pump schemes have been started for smallholders but have not been a success because the cost of fuel and repairs was greater than the farmers' profits from food crops.

There are plans afoot to irrigate 42,000 ha of smallholder crops with gravity fed water in the Lower Shire using a canal constructed for that purpose. Large scale government sponsored irrigation schemes involving many smallholder tenants do not have a good reputation in Africa as a whole and those established in the past in Malawi have also involved both capital and maintenance costs well in excess of the value of production. They have survived because the costs are not passed on to farmers and this new development will be followed with interest. The amount of water available from the Shire River leaves little room for additional expansion and this development will have little impact on national food production.

Much smaller schemes using treadle pumps have demonstrated the value of this form of irrigation as long as the farmers have been able to access additional supplies of fertiliser to nourish the irrigated plants. It is sometimes forgotten by those who see irrigation as the key to Malawi's food problems that we do not as yet have crops which only need water and sunlight and require no nutrients. A more recent development has been the introduction of solar operated pumps and it is hoped that as the cost of this technology declines it will become more widespread, but the note concerning the need for costly supplementary inputs remains the same.

The search for higher valued crops which would justify the use of expensive power to pump water from Lake Malawi continues and one hopes that some new crop will be identified which will satisfy the demand of outsiders that Malawians use their famous lake for irrigation will be fulfilled. In the meantime it is likely to be small scale irrigation with treadle pumps, diversions and water harvesting from which smallholders gain the most benefit.

\section{CONCLUSION}

Many of those concerned with the health of our planet are calling upon farmers to produce "more with less". By this they mean that further increases in crop production should be achieved with more efficient use of intensifying inputs rather than just increasing the amounts being used. This is an entirely reasonable request directed to farmers who use over half a ton 
of fertilizer per ha per year. But how appropriate is it for a Malawian smallholder with half a ha of worked out soil from which the plant nutrients have been depleted by years of cropping when more nutrients have been removed from the soil than have been replaced? The same farmers have scarce opportunities of finding remunerative employment with which to supplement the family income and purchase the inputs vital to increasing the productivity of the smallholding. It is difficult to envisage smallholders who own less than these Malawians. To call for them to increase more with even less than they already have is quite inappropriate. What they need is "more" not "less". Unfortunately most cannot be offered more fertile land with which to increase their productivity. They therefore need help to replenish the nutrients in their existing land. The best way to achieve this would be for them to have access to off-farm employment with reasonable pay so that they could purchase the vital inputs they need. At present there is little sign of such jobs being available in the near future in the numbers that are required.

The alternative is to subsidise inputs so that they become accessible to the large proportion of smallholders who cannot afford them in adequate quantities at commercial prices. It is unfortunate that the poor quality of management of the existing Farm Input Subsidy Programme (FISP) in recent years has given this strategy a bad name and led to the danger of further declines in soil fertility and crop production. What is needed now is a welldeveloped alternative strategy which would put cash into the hands of smallholders in September and October to enable them to buy their inputs directly from commercial suppliers. This would be more cost effective than the current system, should be able to reduce the damaging impact of corruption and would also overcome the late delivery of inputs which has greatly reduced the effectiveness of FISP in recent years. All available evidence indicates that such subsidies would be a lot cheaper than providing supplementary food to millions of families each year. Hopefully those with a genuine concern for the welfare of rural Malawians will be ready to assist them to produce "more with more" rather than continuing with the impossible demand that they should produce "more with less". 


\section{REFERENCES}

Acland, J. D. (1971). East African Crops. An Introduction to the Production of Field and Plantation Crops in Kenya, Tanzania and Uganda. FAO/Longmans. London, UK. pp. 252.

Byerlee, D., Anandajayasekeram, P., Diallo, A., Gelaw, B., Heisey, P., Lopez-Pereira, M., Mwangi, W., Smale, M., Tripp, R., \& Waddington, S. (1994). Maize Research in Sub-Saharan Africa: An Overview of Past Impacts and Future Prospects. CIMMYT Economics Working Paper 94-03. Mexico, D.E: CIMMYT.

Chirwa, E., \& Dorward, A. (2013). Agricultural input subsidies: The recent Malawi experience. Oxford University Press. Oxford, UK. pp. 304.

Chitedze. (?). Malawian Bean Improvement. Department of Agricultural research Annual Report for 1957/58. Government Printer Zomba, Malawi.

Freeman, R. (2000). Cereals and Starches Comparing Production and Consumption National Statistics Office Mimeograph 13/11/00. Zomba, Malawi.

Heisey, P. W., \& Mwangi, W. (1996). Fertilizer use and maize production in sub-Saharan Africa. CIMMYT Economics Working Paper 96-01. Mexico, D.F.: CIMMYT.

Heisey, P. W., \& Smale, M. (1995). Maize Technology in Malawi: A Green Revolution in the Making? CIMMYT Research Report No.4. Mexico, D.F.: CIMMYT.

HIID. (1994). Fertiliser Policy Study: Market Structure, Prices, and Fertiliser Use by Smallholder Maize Farmers. Lilongwe, Malawi. Harvard Institute for International Development. Mimeograph.

Jameson, J. D. (1970). Agriculture in Uganda (2nd edition ed.). Oxford University Press. London, UK. pp. 395.

Kumar Rao, J. V. D. K. (1990). Pigeonpea: Nitrogen Fixation. In Y. L. Nene, S. D. Hall, \& V. K. Sheila (Eds.), The pigeonpea. CAB International. United Kingdom. pp. 233-256.

Kumbira, J., Benesi, I. R., \& Ngma, J. C. (1993). Root and Tuber Crops Report. Cassava breeding. Lunyangwa Research Station, Malawi.

Liwonde. (1982). Liwonde ADD Field Development : On Farm Trial Services Volume 6 1981/82. Annual report. Liwonde Agricultural Development Division. Malawi.

Liwonde. (1988). Liwonde ADD Adaptive Field Trials 1987/88. Annual Report. Liwonde Agricultural Development Division. Malawi.

McSweeney, C., New, M., \& Lizcano, G. (2010). UNDP Climate Change Country Profiles Malawi. United Nations Development Programme.

Miracle, M. P. (1966). Maize in Tropical Africa. University of Wisconsin Press. Madison Wisconsin, USA. pp. 327.

NSO. (2008). Population and Housing Census 2008. Volume 7 Population Projections. National Statistical Office. Zomba, Malawi.

NSO. (2010). National Census of Agriculture and Livestock 2006/07. Main report. National Statistical office. Zomba, Malawi.

NSO. (2014). Malawi Labour Force Survey 2013. National Statistical Office. Zomba, Malawi.

One Acre Fund. (2014). Annual Report for the 2013/14 season. One Acre Project Office Zomba. Malawi. 
Owen, R., Crossley, R., Johnson, T., Tweddle, D., Kornfield, I., Davison, S., Eccles, D., \& Engstrom, D. (1990). Major low levels of Lake Malawi and their implications for speciation rates in cichlid fishes. Proceedings of the Royal Society of London B: Biological Sciences.

Pike, J. G., \& Rimmington, G. T. (1965). Malawi: a Geographical Study. Oxford University Press. London, UK. pp. 229.

Platt, B. S. (1945). Tables of Representative Values of, Foods commonly used in Tropical Countries British Medical Research Council Special Report Series 253.

Reddy, L. (1990). Pigeonpea: morphology. In Y. L. Nene, S. D. Hall, \& V. K. Sheila (Eds.), The pigeonpea. CAB international. Wallingford, UK. pp. 47-87.

Saka, A. R., Green, R. I., \& Ng'ong'ola, D. H. (1995). Soil Management in Sub-Saharan Africa: Proposed Soil Husbandry Plan for Malawi Agricultural Research Policy Unit. Bunda College of Agriculture, 279.

Singh, A., Mehan, V., \& Nigam, S. (1997). Sources of resistance to groundnut fungal and bacterial diseases: an update and appraisal. Information Bulletin Number 50. International Crops Research Institute for the Semi-Arid Tropics. Patancheru, Andhra Pradesh, India

Uleuk, H., \& Chimungu, J. (2015). Conservation Agriculture Situation Analysis. CISANET - Civil Society Agricultural Policy Network. Lilongwe, Malawi.

USAID. (2000). Country Strategic Plan: 2001-2005. Lilongwe, Malawi. United States Agency for International Development.

World Bank. (2004). Malawi - Country Economic Memorandum : Policies for Accelerating Growth. Washington, DC. (C) World Bank. https://openknowledge.worldbank.org/handle/10986/15675 License: CC BY 3.0 Unported. 